\title{
Culture-Free or Culture-Bound? A Boundary Spanning Perspective on Learning in Knowledge Management Systems
}

\author{
Robert M. Mason, Florida State University, USA
}

\begin{abstract}
Knowledge management systems (KMSs) have been criticized as having a North American bias. The cultural dimension of KMSs, particularly the relationship of learning and culture in $K M$ projects, are rarely discussed. This paper addresses these concerns in a review of the conceptual foundations for KM and by examining implementations of KM projects. Despite the evolutionary changes in how KM is viewed, KMSs, as they have been designed, implemented, and reported, do not appear to provide for cultural diversity among users. Instead, the reports of KMSs indicate that such systems seek to create and maintain a homogeneous organizational culture, and the adoption of such a shared culture appears to be a prerequisite for success. The paper discusses KMSs as systems that exhibit boundary spanning objects and processes in three different categories, and an analysis of reported projects reveals that boundary spanning across national and ethnic boundaries is rare.
\end{abstract}

Keywords: knowledge management systems, organizational learning, culture, boundary spanning

INTRODUCTION:

INFORMATION TECHNOLOGY AND KNOWLEDGE MANAGEMENT

Global enterprises increasingly turn to knowledge management systems (KMSs) to raise productivity and remain competitive. Although there is considerable evidence that applications of information technology (IT) for storage and improved access of information help create value, some observers believe that KMSs are limited in their utility because they have been designed with a North American bias (Nonaka, 1995). To understand why this bias may be of concern, it is useful to consider KM programs in the context of the resource-based view (RBV) of the firm (Penrose, 1959).

The dynamic economic environment and the ever-increasing innovative capabilities of global organizations have renewed interest in the RBV. In the opinion of many writers, the RBV has had a significant impact on how information systems and strat- 
egy are viewed. The RBV is closely linked with strategy and sustainable competitive advantage (Barney, 1994, 1996), plays a major role in how the modern economic theory of the firm has developed (Madhok, 2002), and perhaps has become the most influential framework for the theory of strategic management and sustained competitive advantage (Barney et al., 2001). The knowledge-based view (KBV) of the firm, foreseen by Drucker (1988), is a special case of the RBV with a focus on knowledge as an organizational resource (Grant, 1996a,1996b; Spender, 1996).

As in the more general case of the RBV's influence on strategic management and competitive advantage, the KBV provides the conceptual foundation for much of the research and design efforts that link information technology (IT) and systems, strategic IT, organizational learning, and knowledge management systems. The KBV has shaped the discussion of KMSs and the role of information technology in strategy and competitive advantage (Huber, 1991; Mata, 1995; Kogut, 1996; Alavi, 2001). While the KBV is the foundation for IT support of knowledge management, most observers agree that knowledge by itself is not the source of a competitive advantage. Instead, organizations use knowledge to gain a competitive advantage through learning (Stata, 1989), by the development of competencies (Rebentisch \& Ferretti, 1995; Alavi, 2001), and through knowledge integration (Grant, 1996b; Kogut, 1996). In other words, the value of KM programs depends not only on the application of IT but on the individual and organizational learning and knowledge integration that comes from revealing and using all the intellectual assets of the organization. This requires a mix of technology and organizational processes.

From the perspective of the KBV, a global enterprise that has members from distinct ethnic and cultural backgrounds would appear to have a potentially large asset in the rich source of tacit and experiential knowledge of its members. KM efforts would be one way to access this potential asset. This paper addresses the question of how and to what extent firms may be taking advantage of the knowledge asset represented by having members with diverse backgrounds.

In the remainder of the paper, we will use the terms "KM" and "KMS" interchangeably; both will refer to the set of activities directed toward knowledge asset management. Our approach is in the spirit of socio-technical systems, thus KM and KMS include physical resources (e.g., computers and communication infrastructures), conceptual resources (e.g., repositories of expressed knowledge, tacit knowledge), and the social and organizational processes associated with the use of these resources.

The paper contributes to the discussion of KM by drawing attention to the importance of culture in KM efforts and proposing that KMSs may be viewed as boundary spanning systems. The cultural boundary is important for two reasons. First, ethnic backgrounds and national cultures represent a potential knowledge asset of the enterprise. Second, culture is a significant factor in how people learn, and learning is required for the organization to take advantage of the potential intellectual assets in the organization. The paper uses Carlile's boundary spanning framework (Carlile, 2002) to review the functions of KMSs and to examine how these systems handle culture.

In the following three sections, this paper provides a synopsis of knowledge management approaches and learning from three perspectives: a) a summary of the goals and expected benefits of KMSs; b) 
the role and importance of culture and ethnic background in learning; and c) reports on the implementation and use of KMSs and the role of culture in these implementations. The fourth section reviews these KMS implementations using Carlile's framework of practical boundary spanning systems to gain a better understanding of the relative importance of culture in the design and use of a KMS in a particular organization. Based on this review, most KMSs appear to fulfill the boundary spanning role primarily at two of Carlile's three levels. The KM activities at the third level are not directed at spanning boundaries between or among national or ethnic cultures but rather at spanning hierarchical boundaries. As a consequence, benefits that might accrue from the surfacing of differences in tacit cultural knowledge are unlikely to be realized. The final two sections discuss the contribution of this paper, its limitations, and its potential significance for research and practice.

\section{KMS DIRECT AND INDIRECT BENEFITS: THE VALUE OF CULTURE AND LEARNING}

Early studies of KMSs viewed such systems as the application of IT to improve the information value chain (Rayport, 1995) by providing an organizational memory (Walsh \& Ungson, 1991) and supporting organizational learning (Huber, 1991). A recent review of KM elaborates on this basic value chain model and summarizes prior studies as being focused on four basic processes in knowledge work: creating, storing/retrieving, transferring, and applying knowledge, with each of these processes being subjected to more detailed analyses (Alavi, 2001, p. 114). This conceptual model views KMSs as systematic attempts to make visible the collective and individual knowledge in an organization, develop a knowledge-intensive culture, and support this culture through an IT-enabled infrastructure (Davenport \& Prusak, 1998; Alavi, 2001). Specifically, a KMS is viewed as a class of information systems applied to managing knowledge (Alavi, 2001), and IT is seen as an enabler of the basic processes of creating-storing/retrieving-transferring-applying knowledge.

While much effort is devoted to creating repositories of explicit knowledge, KM efforts also seek to identify sources of tacit knowledge, to surface and improve access to this knowledge, and to enable collaborative learning and integration across functional areas (Alavi, 2001; Leonard, 2002; MacCormack, 2002; Fulmer, 2003). In their study of $31 \mathrm{KM}$ projects, Davenport et al. (1998), identified four broad types of objectives: (1) create knowledge repositories, (2) improve knowledge access, (3) enhance knowledge environment, and (4) manage knowledge as an asset.

Reports of tangible benefits have included cost savings (arising from, among other things, reduced time required for knowledge access by having ready access to needed information) and increased revenue and profit. These benefits are recognized as both direct and indirect. Direct benefits are those associated with having the collective knowledge readily accessible to all organizational members: a corporate memory (e.g., best practices, repositories of projects, compilations of data about clients and suppliers, etc.) and the facilitation of communication among the organization's members (a shared structure and communication infrastructure, meta-information that enables members to locate others that may have the information they require), and knowledge transfer (Fulmer, 2003). These direct benefits are antecedents to indirect 
benefits: knowledge creation and innovation in products and processes, improved collaboration and the synthesis of tacit knowledge from multiple entities in the organization, the creation and maintenance of core competencies, and improved competitiveness. The indirect benefits require learning and knowledge integration across functional boundaries and may be even more valuable than the direct benefits. However, as noted by many of the cases, it is easier to see the impact of KM efforts on the direct benefits, and firms are able to assign values to these direct benefits more easily than to indirect benefits (Alavi, 1997; Davenport et al., 1998; Hansen, 2002; MacCormack, 2002; Ng, 2002; Soo, Devinney, et al., 2002). The difficulty of measuring indirect benefits may be overcome by measuring their impact. For example, Soo et al. (2002) suggest measuring changes in the innovative outputs that arise from the KM effort.

A global firm comprises organizations that have individuals from many different ethnic and cultural backgrounds. From the $\mathrm{KBV}$, knowledge from this diverse set of employees represents a potential intellectual asset. Appropriating the benefits from this asset, however, requires learning. The next section reviews the relationship between culture and learning.

\section{LEARNING: THE ROLE OF CULTURE}

Learning is defined as "a relatively permanent change in the ability to exhibit a behavior; this change occurs as the result of a successful or unsuccessful experience"' (Klein \& Mowrer, 1989, p. 2). This definition is consistent with the experiential learning model (Kolb, 1984) and with a prevailing view in the IT field that "an entity learns, if, through its processing of in- formation, the range of its potential behaviors is changed" (Huber, 1991, p. 89). Although these definitions are consistenteach relates to ability or capability to demonstrate behavior, for example - they have differences: Klein and Kolb emphasize experience as the basis of learning; Huber, as an IS researcher, views the learner as an information (or knowledge) processing entity. Huber also posits that an organization learns if "... any of its units acquires knowledge that it recognizes as potentially useful to the organization" (Huber, 1991, p. 89).

Although a discussion of the similarities and distinctions between individual and organizational learning could be interesting and enlightening (e.g., Dixon, 1994), this paper accepts that individual learning is critically important to (if not, as Huber posits, equivalent to) organizational learning. Consequently, the following discussion focuses on individual learning and looks particularly at contemporary theories about culture-based learning.

The study of learning processes has provided a rich field for psychologists for well over 100 years (Mowrer, 1989). Earlier views of learning focused on the stimulus-response relationship and later (particularly Skinner's work) associated reinforcement (rewards) with behavior. Contemporary learning theory, in contrast, has moved away from global theories and looked more closely at concept formation, problem solving, language, and other cognitive aspects of learning. Even the biological aspects of learning are getting new attention (LoLordo, 1989; Mowrer, 1989; Zull, 2002).

Because learning is related to language and language use, and language rules may be "hardwired" as Chomsky proposed in the 1980s (see Baker, 2001, for recent renewal of these arguments), one might 
conclude that the basic biological foundation for learning is genetic and therefore would not vary from culture to culture. A common biological base does not prevent the development and evolution of learning skills and abilities along different paths in distinct ethnic groups and cultures.

Indeed, for over 70 years researchers have examined the link between culture (and ethnicity) and learning. Hall (1959) summarizes the relationship between learning and culture by saying, "once people have learned to learn in a given way, it is extremely difficult to learn in any other way [...C]ulture reflects the way one learns." In 1930, Vygotsky and Luria proposed a culture-centered approach to learning, and others developed this approach further (Vygotsky et al., 1987; Forman et al., 1993; Kozulin, 1998). In this perspective, culture is a source of differences in cognition as cognitive processes are formed through sociocultural activities. Cole and others developed this into a contextual theory of cognitive functions (Cole, 1971), which has as a foundation the idea that different cultures have different systems of mediated learning experience (MLE). Such systems are important to cognitive development, and differences in development (which can arise from different MLEs) become evident when a learner makes a transition from one system to another.

Some have argued "cross-cultural differences tend to disappear under the influence of systematic exposure to formal schooling" (Kozulin, 1998, p. 110, citing Cole, 1990). However, recent research confirms Hall's general statement and provides empirical evidence for Cole's theory that individual cognitive abilities can develop differently in different cultures. Even within the U.S., studies have indicated that some groups exhibit distinct behavioral styles through which they express their abilities to learn. Individuals who have experienced culturally distinct environments while growing up tend to use the skills gained in these environments even after they are adults (Hilliard, 1992). In studies of young adults who have completed schooling in one culture and move to another culture, the results indicate that the nature of the initial formal schooling makes a difference. This difference is not simply a difference in knowledge base, but rather is associated with the basic skills by which one learns new concepts. The young adults exhibited specific difficulties associated with coding schema, concepts, and graphic and symbolic devices used in communication of ideas (e.g., tables, ordering, plans and maps). The difficulties extend to cognitive activities such as the ability to identify or define problems (that is, the ability to apply their knowledge to a set of data and infer the implicit question or issue), the ability to work with multiple sources of information, etc. In short, the young adults are missing cognitive antecedents that would enable them to excel in their new environment (Kozulin, 1998). Kozulin concludes, “...cross-cultural differences in cognition are most probably related to learning practices characteristic of different cultures and subcultures..." and "Two major determinants of cognitive prerequisites are conceptual literacy and facility with other symbolic psychological tools, and a mediated learning experience responsible for the integration of these tools into the cognitive system of the student" (Kozulin, 1998, p. 129). His work showed that intervention could help learners develop the basic skills that would enable them to learn effectively in the new environment.

Research on western-style education has included considerable recent interest in problem-based learning (PBL) as a dis- 
tinct pedagogy. The potential benefit of PBL is that it provides a better match of formal learning experience with environmental demands after the completion of formal schooling. While some research reports mixed results, there is considerable enthusiasm for this approach in the sciences and medicine (Culatta, 1994; Boud \& Feletti, 1998; Jones et al., 2001). The use of PBL to develop competencies - abilities that enable persons to continue to learnis suggested by Tien, et al. (2003), who compare the competencies identified as goals by the educational systems in Australia, the UK, the U.S., Canada, and Taiwan. Significantly for this review, the competencies in different countries are similar but not identical in wording. For example, Australia and the UK emphasize instrumental competencies more so than the U.S., Canada, and Taiwan. Taiwan lists "selfunderstanding and potential development" as one of its ten competencies, a skill not articulated by any of the other countries' educational systems (Tien, 2003). Tien's study illustrates that even with many shared goals, the educational objectives of even industrialized countries have differences; the differences across a wider range of countries might be even greater.

Kozulin's studies suggest that cultural backgrounds can perform a critical role in the development of problem definition and problem solving abilities. Moreover, intervention to develop missing skills may be required for a learner to make a successful transition from one learning system to another. Since many KMSs are intended to support group problem solving and learning across functional boundaries, a PBL approach may be a useful way to bridge cultural differences, as suggested by Tien (2003). However, there are practical difficulties in designing PBL interventions for non-western and non-English speaking stu- dents (Walker, 1996; Allen \& Rooney, 1998).

\section{KMS IMPLEMENTATIONS AND CULTURE}

This study examined published reports of KMSs in the literature and focused particularly on the role of culture in KMS and KM project success. For individual cases, this section draws heavily on teaching cases (business school cases of individual implementations) and other summaries of actual implementations (e.g., Davenport et al., 1998). Table 1 summarizes the findings, including this author's summary of what appear to be critical success factors in each case. Table 2 provides additional examples of the implementations summarized by Davenport et al. (1998).

The results of the studies summarized in Tables 1 and 2 are striking in three ways. First is the emphasis by so many of the implementations on standardization, both technical standards and the format of the content. Second is the frequent mention that an organizational culture of knowledge sharing is a correlate of success. Third is the prevalent, though not universal, use of incentives to change behavior and encourage system use. National culture and ethnic background of the users are rarely mentioned.

Only one case directly discusses the importance of national culture. In the Buckman Laboratories case, national culture and non-English speakers were handled explicitly (Fulmer, 2003). K'Netix, as it evolved, encouraged contributions to the knowledge base in whatever language the contributor felt most comfortable. A key component of the system was a group of translators hired by the firm. The translators translated into English the contributions selected by the forum monitors, mak- 
Table 1: Characteristics and Critical Success Factors (CSFs) of Sample KMSs

\begin{tabular}{|c|c|c|c|c|}
\hline Source & Context/Users & $\begin{array}{l}\text { Technology } \\
\text { and Methods }\end{array}$ & $\begin{array}{c}\text { CSFs } \\
\text { (author's summary) }\end{array}$ & $\begin{array}{c}\text { Support for } \\
\text { multiple } \\
\text { cultures? }\end{array}$ \\
\hline (Massey, 2002) & $\begin{array}{l}\text { Nortel New Product } \\
\text { Development (NPD) } \\
\text { teams }\end{array}$ & $\begin{array}{l}\text { Electronic } \\
\text { Performance } \\
\text { Support } \\
\text { System } \\
\end{array}$ & $\begin{array}{l}\text { Financing } \\
\text { Standardized process } \\
\text { Codified format }\end{array}$ & No \\
\hline $\begin{array}{l}\text { (MacCormack, } \\
\text { 2002) }\end{array}$ & $\begin{array}{l}\text { Siemens ShareNet- } \\
\text { multiple (sales, } \\
\text { developers, managers) }\end{array}$ & $\begin{array}{l}\text { Knowledge } \\
\text { Repository } \\
\text { User Network } \\
\text { for query- } \\
\text { response }\end{array}$ & $\begin{array}{l}\text { Structured inputs } \\
\text { Query-Response } \\
\text { component } \\
\text { Marketing of system use; } \\
\text { incentives }\end{array}$ & No \\
\hline $\begin{array}{l}\text { (Fulmer, 1999; } \\
\text { Fulmer, 2000; } \\
\text { Fulmer, 2003) }\end{array}$ & Buckman Labs K'Netix & $\begin{array}{l}\text { Monitored but } \\
\text { unmoderated } \\
\text { Forums } \\
\text { Email }\end{array}$ & $\begin{array}{l}\text { Principles } \\
\text { Code of Ethics } \\
\text { Adaptability } \\
\text { Dedicated staff }\end{array}$ & $\begin{array}{l}\text { Sensitive to culture } \\
\text { Tried multiple } \\
\text { languages; } \\
\text { settled on English } \\
\text { only }\end{array}$ \\
\hline$(\mathrm{Ng}, 2002)$ & $\begin{array}{l}\text { PwC KnowledgeCurve; } \\
99 \% \text { of } 150,000 \text { world- } \\
\text { wide consultants }\end{array}$ & $\begin{array}{l}\text { Intranet; Lotus } \\
\text { Notes } \\
\text { databases }\end{array}$ & $\begin{array}{l}\text { KM content process } \\
\text { (editing/vetting) } \\
\text { Users' view as integrated } \\
\text { system } \\
\text { Access from any location }\end{array}$ & No \\
\hline $\begin{array}{l}\text { (Leonard, } \\
\text { 2002) }\end{array}$ & $\begin{array}{l}\text { NASA/JPL: LLIS, APPL } \\
\text { and KSI (face-to-face } \\
\text { program); Project } \\
\text { Libraries; Know Who } \\
\text { directory; Technical } \\
\text { Questions DB; legacy } \\
\text { reviews; personal } \\
\text { knowledge organizers } \\
\text { (oral histories) }\end{array}$ & $\begin{array}{l}\text { Customizable } \\
\text { portal; } \\
\text { DocuShare, } \\
\text { leadership } \\
\text { development; } \\
\text { Internet; DBs }\end{array}$ & $\begin{array}{l}\text { Resources } \\
\text { Culture and commitment } \\
\text { (varied from low to high) }\end{array}$ & $\begin{array}{c}\text { No } \\
\text { (Focus is on US } \\
\text { organization) }\end{array}$ \\
\hline $\begin{array}{l}\text { (Rukstad, } \\
\text { 2001) }\end{array}$ & $\begin{array}{l}\text { DaimlerChrysler } \\
\text { Knowledge Management } \\
\text { Strategy }\end{array}$ & $\begin{array}{l}\text { CAD/CAM } \\
\text { Product DB } \\
\text { EBOKs } \\
\text { TechClubs }\end{array}$ & $\begin{array}{l}\text { Support } \\
\text { Link to performance } \\
\text { Top management } \\
\text { consensus on required } \\
\text { capabilities }\end{array}$ & No \\
\hline
\end{tabular}

Table 2: Examples from "Successful Knowledge Management Projects" (Adapted from Davenport et al.,1998)

\begin{tabular}{|c|c|c|}
\hline Context/Users & Technology and Methods & Notes \\
\hline HP (9 projects) & $\begin{array}{l}\text { Electronic Sales Partner } \\
\text { Lotus Notes DB }\end{array}$ & $\begin{array}{l}\text { Highly enthusiastic managers ("most } \\
\text { successful implementation of } \\
\text { software I have seen in } 20 \text { years") }\end{array}$ \\
\hline Sequent Computer & $\begin{array}{l}\text { Sales oriented document } \\
\text { respository }\end{array}$ & Highly enthusiastic managers \\
\hline $\mathrm{BPX}$ & $\begin{array}{l}\text { Videoconferencing } \\
\text { Document scanning/sharing } \\
\text { Education, support }\end{array}$ & Anecdotal success stories \\
\hline Microsoft & $\begin{array}{l}\text { Breakout of } \mathrm{K} \text { competencies } \\
\text { Link K competencies to staffing } \\
\text { and HR }\end{array}$ & \\
\hline $\begin{array}{l}\text { National } \\
\text { Semiconductor }\end{array}$ & \begin{tabular}{|l|} 
Intranet \\
Lotus Notes
\end{tabular} & $\begin{array}{l}\text { Engineers preferred Intranet; sales and } \\
\text { marketing preferred Notes }\end{array}$ \\
\hline $\begin{array}{l}\text { TelTech Resource } \\
\text { Network }\end{array}$ & $\begin{array}{l}\text { Referral of experts (technology } \\
\text { not specified) } \\
\text { Customer feedback } \\
\text { Records of K resources used in } \\
\text { proposals and projects } \\
\text { compared with "wins" }\end{array}$ & Basis for business model \\
\hline Sematech & $\begin{array}{l}\text { Formal K transfer practices } \\
\begin{aligned} & \text { a. } \mathrm{K} \text { transfer } \\
& \text { organization } \\
& \text { b. K transfer sessions } \\
& \text { c. } \text { Client "assignees" }\end{aligned}\end{array}$ & $\begin{array}{l}\text { Face-to-face most effective for } \mathrm{K} \\
\text { transfer }\end{array}$ \\
\hline Consulting firm & Structured $\mathrm{K}$ base & $\begin{array}{l}\text { Contributions to K base a significant } \\
\text { factor in compensation (not entirely } \\
\text { successful) }\end{array}$ \\
\hline Automobile co. & $\begin{array}{l}\text { Specific K application guidelines } \\
\text { Decision audits to assess use of } \\
\text { Knowledge }\end{array}$ & Success not established \\
\hline
\end{tabular}

Copyright (C) 2003, Idea Group Inc. Copying or distributing in print or electronic forms without written permission of Idea Group Inc. is prohibited. 
ing these contributions more accessible to employees whose native language was not English. As the system evolved, separate regional forums began, including a Spanish language case database on best practices. In 1997 there were 1,787 cases in English and 685 in Spanish (Fulmer, 2003). At the last report, however, the firm had standardized on English as the common language for contributions, rather than having separate language forums (Fulmer, 2000). Consequently, the only case that gave attention to national culture appears to have "regressed to the mean" and decided on a standardized approach to knowledge sharing.

This review of KM contrasts with the attention paid to culture in studies of other information systems, (e.g., Walsham, 2002) and in other studies of international management, (e.g., Erez \& Earley, 1993). The tendency to ignore cultural background in $\mathrm{KM}$ efforts suggests that KMS designers may be implicitly adopting the "culturefree" hypothesis as a basis for design. The culture-free hypothesis expresses the thought that there is universality to organizational design and structures - that organizations are micro social entities that can exist without reference to their immediate societal environment. This is in contrast to the culture-bound view that organizations match their structures to fit their societal environment (Maurice, 1976). For a wide range of production firms, the culture-free hypothesis is supported by a meta-analysis (Miller, 1987). There is some evidence supporting the culture-free hypothesis in banks (Birnbaum, 1985), but research that examines this hypothesis in other professional service work is missing. Perhaps the lack of attention to (national) culture in $\mathrm{KM}$ efforts is understandable, particularly given the experience and decision of Buckman Laboratories, but there is no re- search that supports "culture-free" as a normative approach to knowledge work (or other professional service work).

\section{KMSS AS BOUNDARY SPANNING SYSTEMS}

Boundary spanning has been recognized as a necessary component in processes that require coordination and translations among diverse groups (Star \& Greisemer, 1989) and different functional groups or "thought worlds" (Dougherty, 1992). Product development is an example of a process requiring such coordination. $\mathrm{KM}$ and learning are often discussed in the context of new product development (NPD) processes; (Chapman \& Hyland, in press; Verganti, 1998; Ramesh and Tiwana, 1999; Alavi, 2001).

Carlile's (2002) study of boundary spanning objects in an NPD process suggests a useful framework for examining the functions of KMSs. Carlile looked at the four primary functions involved in the creation of a new product (sales/marketing, design engineering, manufacturing engineering, and production) and examined how the new product development team dealt with the specialized knowledge of each area. Each of the four functional areas had different and specialized (in Carlile's terms, "localized and embedded") knowledge, structured in a way that made sense to the group. This knowledge specialization presented a barrier to the effective operation of the NPD team - the team found it difficult to exchange and synthesize knowledge as necessary for the successful development of a new product. Carlile observed that the team overcame this barrier by using boundary spanning objects that operated at three different levels: syntactic, semantic, and pragmatic.

At the syntactic level, repositories 
enabled communication of facts and agreed-upon tasks and actions. At the semantic level, standardized forms and methods enabled not only communication of facts, but also provided a way for the different groups to clarify differences in meaning. The objects at this semantic level (standard forms and methods) enabled the team to translate the knowledge embedded in one group so that other groups contributing to the product development could understand it. At the pragmatic level, $o b-$ jectives, maps, and models enabled each group to transform embedded knowledge into knowledge that the team (and others not in the group) could understand.

Earlier, Brown and Duguid (1998) pointed out different roles of boundary spanning activity, noting particularly the need for translators between communities. In commenting on Carlile's model, Brown (2002) suggests that Carlile's three levels correspond to three different levels of knowledge ambiguity among communities of practice. At each level, different types of boundary objects are necessary for communication, knowledge transfer, and learning.

At the syntactic level, the differences across the boundaries are explicit, clear, and stable. A shared syntax is a necessary (but not necessarily sufficient) condition for knowledge sharing under these conditions. Taxonomies and classification (e.g., shared databases) provide this syntax and enable the sharing and transfer of knowledge among groups that have a clear understanding of their differences and understand that these differences are relatively stable.

At the semantic level, the differences are neither clear nor necessarily stable (Brown, 2002), and the solution is to provide a means of translating meanings across boundaries. At this level, Carlile (2002) observed the use of standardized forms and methods as boundary objects.

At the pragmatic level, Brown (2002) notes that the knowledge of one group is not neutral to another's. The communities may have different values and/or power relationships, and this level of difference requires boundary objects that provide additional capability beyond the first two levels. At this level, the groups must transform their knowledge and create new (shared) knowledge rather than simply exchanging or transferring knowledge. Resolution of the group differences requires objects such as models and maps, objects that enable the sharing of methods of thinking and the surfacing of assumptions and values. Only when both groups understand these differences can the two communities be co-creators of knowledge that did not exist before the differences were discussed. It is at this level that one might observe the kind of knowledge integration and synergy anticipated by the KBV of the firm.

Considering KM efforts and KMSs as processes to span the boundaries of groups that have different knowledge and experience, one can map the examples from Tables 1 and 2 onto Carlile's framework. At the syntactic level, shared databases (e.g., repositories of best practices, evident in all the cases) provide a way for groups to transfer knowledge. At the semantic level, standard forms and practices (highlighted in Nortel, Siemens, PwC, EYKnowledgeWeb, KPMG's KWeb and Andersen's Knowledge Xchange) provide the means of representation of different knowledge in familiar formats and a means of learning from groups that have a different knowledge base.

At the pragmatic level, where differences in value would be apparent, Tables 1 and 2 provide fewer examples. The use of principles (Buckman Laboratories) as a 
boundary-spanning object between upper management (the owner) and employees could be considered a pragmatic level object, helping transform the owner's values into practice. An interesting distinction is that the principles are not developed in collaboration with the employees but rather presented to them as a standard - a codified set of behavioral principles that enable them to understand the goals and objectives of the firm. Similarly, one may consider the incentives and efforts to change corporate culture as boundary spanning activities at the pragmatic level. ${ }^{1}$ These activities may also be viewed as procedures and routines that serve to translate values from the executive level to managers and other employees - procedures that might also be viewed as semantic. In other words, these processes span a hierarchical boundary, not an ethnic or national cultural boundary.

Table 3 summarizes Carlile's levels, Brown's (2002) view of the community dif- ferences for which spanning is required, and the corresponding boundary spanning techniques used by KMSs. Note that all of the KM efforts report use of syntactic boundary objects (repositories).

Table 4 presents the examples in Table 1 in terms of the different boundary objects in Carlile's model. Most objects and processes span communities of practice (e.g., different functional groups) at the syntactic or semantic level, and the majority are operating at the syntactic levelthat is, most of the KMSs are set up to facilitate the exchange of knowledge at the level where the knowledge differences are, in Brown's (2002) words, "clear and stable." (The leadership development process at NASA/JPL, assuming it includes dialogue among individuals with different values, is an example of a process operating at the pragmatic level, but the literature provides little detail.) All behavioral change processes and exercise of power (incentives, top management support, etc.) are

Table 3: Levels and Functions of Boundary Spanning Processes with KMS Examples

\begin{tabular}{|c|c|c|c|c|}
\hline $\begin{array}{l}\text { Level } \\
\text { (Carlile, } \\
\text { 2002) }\end{array}$ & $\begin{array}{l}\text { Community } \\
\text { Differences } \\
\text { (Brown, 2002) }\end{array}$ & $\begin{array}{l}\text { Boundary Object } \\
\text { Function or } \\
\text { Solution-adapted } \\
\text { from (Brown, } \\
2002 \text { ) }\end{array}$ & $\begin{array}{l}\text { KMS Boundary } \\
\text { Objects }\end{array}$ & Example KMS \\
\hline Pragmatic & $\begin{array}{l}\text { Knowledge is } \\
\text { not neutral; } \\
\text { values and } \\
\text { power may } \\
\text { differ across } \\
\text { boundaries }\end{array}$ & $\begin{array}{l}\text { Transformation } \\
\text { Exercise of power }\end{array}$ & $\begin{array}{l}\text { Objectives } \\
\text { Maps } \\
\text { Models } \\
\text { Incentives } \\
\text { Forums }\end{array}$ & $\begin{array}{l}\text { Buckman Labs } \\
\text { Siemens } \\
\text { Andersen } \\
\text { E\&Y } \\
\text { KPMG } \\
\text { Others (Davenport, } \\
\text { Long et al. 1998) } \\
\text { Buckman Labs } \\
\text { NASA/JPL }\end{array}$ \\
\hline Semantic & Unclear & Translation & $\begin{array}{l}\text { Principles } \\
\text { Standard methods } \\
\text { and procedures } \\
\text { Standard, codified } \\
\text { forms }\end{array}$ & $\begin{array}{l}\text { BuckmanLabs K'Netix } \\
\text { Nortel } \\
\text { E\&Y } \\
\text { Andersen } \\
\text { PwC }\end{array}$ \\
\hline Syntactic & Clear, stable & $\begin{array}{l}\text { Communication } \\
\text { Shared knowledge } \\
\text { and data base }\end{array}$ & Repositories & All \\
\hline
\end{tabular}


Table 4. KMSs as Boundary Spanning Systems

\begin{tabular}{|c|c|c|c|c|}
\hline \multirow[t]{2}{*}{ KMS, KM effort } & \multirow[t]{2}{*}{ Boundary Objects or Processes } & \multicolumn{3}{|c|}{$\begin{array}{l}\text { Level in Carlile's } \\
\text { Framework }\end{array}$} \\
\hline & & के & 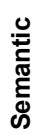 & 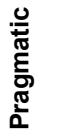 \\
\hline $\begin{array}{l}\text { Nortel New Product Development } \\
\text { (NPD) teams }\end{array}$ & $\begin{array}{l}\text { Financing } \\
\text { Standardized process } \\
\text { Codified format }\end{array}$ & $\begin{array}{l}x \\
x \\
x\end{array}$ & $\begin{array}{l}x \\
x\end{array}$ & \\
\hline $\begin{array}{l}\text { Siemens ShareNet-multiple } \\
\text { (sales, developers, managers) }\end{array}$ & $\begin{array}{l}\text { Structured inputs } \\
\text { Query-Response } \\
\text { Incentives }\end{array}$ & $\mathrm{X}$ & $\begin{array}{l}X \\
X\end{array}$ & $\mathrm{X}$ \\
\hline Buckman Labs K'Netix & $\begin{array}{l}\text { Forums } \\
\text { Code of Ethics } \\
\text { Principles }\end{array}$ & $\mathrm{X}$ & $\begin{array}{l}X \\
X \\
X\end{array}$ & $\begin{array}{l}X^{*} \\
X\end{array}$ \\
\hline $\begin{array}{l}\text { PwC KnowledgeCurve; } 99 \% \text { of } \\
150,000 \text { world-wide consultants }\end{array}$ & $\begin{array}{l}\text { Users' view as integrated system } \\
\text { KM content process (editing/vetting) }\end{array}$ & $\begin{array}{l}X \\
X\end{array}$ & $\mathrm{X}$ & \\
\hline $\begin{array}{l}\text { NASA/JPL: LLIS, APPL and KSI } \\
\text { (face-to-face program); Project } \\
\text { Libraries; Know Who directory; } \\
\text { Technical Questions DB; legacy } \\
\text { reviews; personal knowledge } \\
\text { organizers (oral histories) }\end{array}$ & $\begin{array}{l}\text { Resources } \\
\text { Portal } \\
\text { DocuShare } \\
\text { DBs } \\
\text { Leadership Development }\end{array}$ & $\begin{array}{l}x \\
x \\
x \\
x\end{array}$ & $\mathrm{x}$ & $\mathrm{X}$ \\
\hline $\begin{array}{l}\text { DaimlerChrysler Knowledge } \\
\text { Management Strategy }\end{array}$ & $\begin{array}{l}\text { CAD/CAM } \\
\text { Product DB } \\
\text { EBOKs } \\
\text { TechClubs }\end{array}$ & $\begin{array}{l}X \\
X \\
X \\
X\end{array}$ & $\mathrm{X}$ & \\
\hline E\&Y: EYKnowledgeWeb & $\begin{array}{l}\text { Lotus Notes } \\
\text { Performance reviews }\end{array}$ & $\mathrm{X}$ & $\mathrm{X}$ & $\mathrm{X}$ \\
\hline $\begin{array}{l}\text { Andersen Consulting: Knowledge } \\
\text { Xchange }\end{array}$ & $\begin{array}{l}\text { Pre-filtered respositories } \\
\text { K Managers with specialized roles } \\
\text { Annual reviews }\end{array}$ & $\mathrm{X}$ & $\begin{array}{l}X \\
X \\
X\end{array}$ & $\mathrm{X}$ \\
\hline KPMG: Kweb & Intranet & $\mathrm{X}$ & & \\
\hline
\end{tabular}

* Only this boundary spanning object/process specifically recognizes cultural distinctions; other pragmatic level objects span top executive and employee communities and may relate more to power than to sharing of knowledge

classified as "pragmatic" processes that span the boundary between executives and other employees - a hierarchical boundary spanning process. Only the forums of Buckman Labs explicitly recognize the role of national culture and provide the opportunity for knowledge to be shared across ethnic boundaries and national backgrounds. The latest report suggested that these forums now are using a single language (English) for sharing knowledge.

\section{CONCLUSIONS AND DISCUSSION}

The intellectual foundation for KM is the KBV of the firm. For global enter- prises, the tacit and experiential knowledge of staff from different cultures is a potential knowledge asset, one that a KM effort might seek to exploit. However, reviews of KMSs and KM efforts revealed little attention directed toward the cultural or ethnic backgrounds of staff. National and ethnic culture are not important considerations in most $\mathrm{KM}$ efforts. There is, however, a universal emphasis on creating and maintaining an organizational culture that supports knowledge exchange and the use of the KMS. Indeed, the success of these $\mathrm{KM}$ efforts seems linked to establishing and rewarding a shared organizational culture. The research identified only one systemBuckman Labs - that explicitly recognized 
the potential value in different national cultures. The latest report on this system indicates that the decision has been made to emphasize English and thus provide a common language base for all employees, so the sole example of a KM that had national culture as a significant dimension has discarded this factor in its latest incarnation.

When examined using the lens of Carlile's pragmatic view of boundary objects, current KMSs and knowledge management efforts have emphasized the syntactic (knowledge transfer) and semantic (knowledge translation) levels of boundary spanning. Boundary spanning at the pragmatic (knowledge transformation and learning) level has focused on internal cultural and behavioral change (related to administrative power) rather than capturing and exploiting knowledge from diverse national or ethnic cultures.

Present-day KM efforts are richer in vision and technique than earlier KM implementations that had a primary emphasis on computer-based repositories of readily available data and knowledge - they include processes and forums in which people exchange knowledge face to face, for example. However, even current KM efforts have not explicitly recognized the potential value of objects and processes that operate at the pragmatic level to span cultural boundaries. It may be that boundary spanning at this level is required to realize the full potential of knowledge integration and co-creation of new knowledge from culturally diverse groups.

Based on this review, it appears that current KM efforts have developed consistent with the "culture-free" hypothesis. That is, by not taking into account multiple national cultures or ethnic backgrounds, these KM efforts tacitly adopt the position that a single organizational culture is appropriate without regard for the societal environment.

This finding raises several issues. The "culture-free" hypothesis is not consistent with other studies that examine culture in IT applications such as group support systems (Watson, 1994) and software production (Walsham, 2002). This raises the question of whether KM is going through a temporary phase and will evolve to a more culturally sensitive form of management, or if KM, as organizational processes and structures seem to be doing for production organizations, will appear the same regardless of cultural environment or the cultural composition of the organization. The stated goal of KM efforts is to achieve knowledge integration and benefit from the collective knowledge of the organization through learning. Because learning is so dependent on cultural experience, it remains an open question if the current culture-free approach is better. Can a culture-free approach enable a KM effort to effectively surface, or otherwise benefit from, the tacit knowledge of its staff from different cultures, the component of the "collective knowledge assets" that comes with the staff? More fundamentally, if KM is intended to exploit the entirety of the organization's intellectual assets, why do current systems appear to have ignored this ethnic and cultural component of the organization's collective knowledge? If organizations truly value all components of the collective knowledge, then KM efforts should pay more explicit attention to the use of objects and processes at the pragmatic level to span cultural boundaries.

By reviewing contemporary learning theory and showing the relationship of culture to learning in the context of knowledge management and knowledge management systems, this paper contributes to the KM discussion by directing attention to the cultural aspects of KM. The paper also 
highlights what may be a limitation of current KM efforts by viewing them as boundary-spanning systems that often operate at two of the levels in Carlile's model - the syntactic and the semantic — but not always at the pragmatic level.

The research in this paper has been limited to secondary reports of KM efforts taken from the management and information systems literature. Consequently, it has all the limitations that come with depending on the reports of others. Constraints of time and space, and the author's judgment on dealing with these constraints mean that the research may have missed significant reports from other fields. The paper also is limited by the scope of the reviewed literature. It represents a review of the recent KM literature and, while it examined the strategic links of KM to the KBV of the firm, the paper did not critically examine the fundamental assumptions in knowledge ontology and epistemology. The paper did not review, for example, ERP systems and other strategic systems that impose structure on entire organizations. A comparison of such systems with KM efforts might lead to different conclusions and different insights. Moreover, the paper did not examine the philosophical, linguistic, and semiotic foundations for the "syntactic, semantic, and pragmatic" levels in Carlile's boundary spanning model. Such an investigation might provide a richer set of explanations and models with which to improve our understanding of the complex practice of sharing and developing knowledge in organizations.

\section{IMPLICATIONS FOR KM RESEARCH AND PRACTICE}

The findings raise several questions about the current designs of KMSs and the evolution of KM. Missing in current discussions of KMSs is a discussion of the potential knowledge assets represented by culturally diverse staff in global organizations. Despite the KM goals of tapping into all parts of the collective knowledge in the firm, this cultural aspect of the organization's knowledge appears, from published reports, to be neglected. Without research on its value, one cannot say that this culturally based set of assets has sufficient value to deserve more formal recognition in $\mathrm{KM}$ efforts.

KM efforts appear to be adopting, without debate or research support for its efficacy, a culture-free design. Research is needed to determine if this culture-free approach is most appropriate for KM, or if other, more culturally sensitive approaches to KM would enable an organization to realize even greater benefits than it can realize using current practices. As researchers, we may want to look toward the critical review of our models of KM (e.g., (Schultze, 2002), and to consider the suggestion that we re-frame our systems as supporting emergent knowledge (Markus et al., 2002), in order to think "outside the box" of the prevailing view of KM as applications of IT to improve the information value chain. If a culture-free approach is judged to be appropriate, then research is needed to understand if an intermediate step is necessary to enable individuals from nonwestern (non-North American) cultures to adapt to these approaches.

From a practical viewpoint, the research suggests that current KM efforts may need to give added attention to the learning dimension of their portfolio of activities. Contemporary learning theory shows a strong relationship between learning and cultural experience-individuals learn based on how they have learned in the past, and early ethnic and cultural ex- 
periences provide a base of models and abilities that enhance and constrain an individual's capabilities in new situations. The implication of these theories for KM practice is two-fold. First, staff from different ethnic and cultural backgrounds will not necessarily share a basic set of models when they begin with their new firm, and these staff may benefit from efforts to bridge the gap in meta-learning skills and models. The frequent reports of KM efforts to reward use of a KMS (conform to a corporate norm) may reflect one approach to bridging this gap, but typically these have been reported simply as efforts for corporate cultural change. Second, if a firm is to benefit from the tacit knowledge these staff members bring with them, it may need to incorporate processes and techniques that are not evident in current examples of KM efforts.

\section{ACKNOWLEDGMENTS}

This paper is significantly different from an earlier version, and the author thanks Roberto Evaristo and three anonymous reviewers for thoughtful and insightful comments that led to this revision.

\section{ENDNOTE}

${ }^{1}$ The author thanks an anonymous reviewer for pointing out that incentives and other behavioral change processes could be classified in this way.

\section{REFERENCES}

Alavi, M. (1997). KPMG Peat Marwick U.S.: One Giant Brain. Cambridge, MA, HBS: Report No. 9-397-108; $21 \mathrm{pp}$.

Alavi, M., and Dorothy E. Leidner (2001). "Review: Knowledge Management And Knowledge Management Systems:
Conceptual Foundations And Research Issues," MIS Quarterly, 25(1): 107-136.

Allen, R. and P. Rooney (1998). "Designing A Problem-Based Learning Environment For ESL Students In Business Communication." Business Communication Quarterly 61(2): 48.

Barney, J. and M. Wright, et al. (2001). "The Resource-Based View Of The Firm: Ten Years After 1991." Journal of Management 27(6): 625-641.

Birnbaum, P. H., and G.Y.Y. Wong (1985). "Organizational Structure of Multinational Banks in Hong Kong from a Culture-Free Perspective." Administrative Science Quarterly 30(2), 262-277.

Boud, D. and G. Feletti (1998). The Challenge Of Problem-Based Learning. London, Kogan Page.

Brown, J. S. (2002). An Epistemological Perspective on Organizations and Innovations. Organizational Knowledge and Learning Conference 2002, Athens.

Brown, J. S., and P. Duguid (1998). Organizing Knowledge. California Management Review 40(1): 90-111.

Brown, J. S. and P. Duguid (2001). "Knowledge and Organization: A SocialPractice Perspective." Organization Science 12(2): 198-213.

Carlile, P. R. (2002). "A Pragmatic View Of Knowledge And Boundaries: Boundary Objects In New Product Development." Organization Science 13(4): 442-255.

Chapman, R. and P. Hyland "Complexity And Learning Behaviors In Product Innovation." Technovation; In Press.

Chard, A. M. (1997). Knowledge Management at Ernst \& Young. Stanford, Graduate School of Business, Leland Stanford Junior University: 28.

Cole, M. (1971). The Cultural Context Of Learning And Thinking: An Exploration In Experimental Anthropology. New York, Basic Books.

Culatta, E. (1994). "New Modes for 
Making Scientists." Science 266(5186): 875+877+883-884+888.

Davenport, T. H., D. W. D. Long, et al. (1998). "Successful knowledge management projects." Sloan Management Review 39(2): 43.

Davenport, T. H. and L. Prusak (1998). Working Knowledge : How Organizations Manage What They Know. Boston, Mass, Harvard Business School Press.

Dixon, N. M. (1994). The Organizational Learning Cycle: How We Can Learn Collectively. New York, McGrawHill.

Dougherty, D. (1992). "Interpretive Barriers to Successful Product Innovation in Large Firms." Organization Science 3(2): 179-202.

Drucker, P. F. (1988). "The Coming of the New Organization." Harvard Business Review 66(1): 45.

Erez, M. and P. C. Earley (1993). Culture, self-identity, and work. New York, Oxford University Press.

Forman, E. A., N. Minick, et al. (1993). Contexts for learning : sociocultural dynamics in children's development. New York, Oxford University Press.

Fulmer, W. E. (1999). Buckman Laboratories (B). Cambridge, MA, Harvard Business School: Report No. 9800-033; 2pp.

Fulmer, W. E. (2000). Buckman Labs (A) Teaching Note. Cambridge, Harvard Business School: Report No. 5-800-360.

Fulmer, W. E. (2003). Buckman Laboratories (A). Cambridge, MA, Harvard Business School: Report No. 9800-160;15pp.

Grant, R. M. (1996a). "Prospering in dynamically-competitive environments: Organizational capability as knowledge integration." Organization Science 7(4): 375.

Grant, R. M. (1996b). "Toward a knowledge-based theory of the firm." Stra- tegic Management Journal 17(Winter): 109122.

Hall, E. T. (1959). The Silent Language. New York, Doubleday \& Co.

Hansen, M. T., Thomas H. Davenport (2002). Knowledge Management at Andersen Consulting. Cambridge, MA, HBS: 14.

Hilliard, A. G., III (1992). "Behavioral Style, Culture, and Teaching and Learning." Journal of Negro Education Africentrism and Multiculturalism: Conflict or Consonance, 61(3), : 370-377.

Huber, G. (1991). "Organizational Learning: The Contributing Processes and Literatures." Organization Science 2(1): 88-115.

Jones, R., R. Higgs, et al. (2001). "Changing face of medical curricula." The Lancet 357(9257): 699-703.

Klein, S. B. and R. R. Mowrer (1989). Contemporary Learning Theories: Instrumental Conditioning Theory And The Impact Of Biological Constraints On Learning. Hillsdale, N.J., Lawrence Erlbaum Associates.

Kogut, B., and Zander, U. (1996). "What firms do? Coordination, identity, and learning." Organization Science 7(5): 502-518.

Kolb, D. A. (1984). Experiential Learning: Experience as The Source of Learning and Development. Englewood Cliffs, NJ, Prentice-Hall, Inc.

Kozulin, A. (1998). Psychological Tools : A Sociocultural Approach To Education. Cambridge, Mass. ; London, Harvard University Press.

Leonard, D., and David Kiron (2002). Managing Knowledge and Learning at NASA and the Jet Propulsion Laboratory (JPL). Cambridge, MA, Harvard Business School: 30.

LoLordo, V. M., and Anastasia Droungas (1989). Selective Associations and Adaptive Specializations: Taste Aversions and Phobias; in Contemporary 
Learning Theories: Instrumental Conditioning Theory and the Impact of Biological Constraints on Learning. S. B. Klein, and Robert R. Mowrer (eds). Hillsdale, NJ, Lawrence Erlbaum Associates: $145-180$.

MacCormack, A. (2002). Siemens ShareNet: Building a Knowledge Network. Cambridge, MA, Harvard: report no. 9-800-160;27pp.

Madhok, A. (2002). "Reassessing The Fundamentals And Beyond: Ronald Coase, The Transaction Cost And Resource-Based Theories Of The Firm And The Institutional Structure Of Production." Strategic Management Journal 23(6): 535.

March, A. (1997). A Note on Knowledge Management. Cambridge, MA, HBS: Report No. 9-398-031; 20pp.

Markus, M. L., A. Majchrzak, et al. (2002). "A Design Theory For Systems That Support Emergent Knowledge Processes." MIS Quarterly 26(3): 179.

Massey, A. P., Mitzi M. MontoyaWeiss, and Tony M. O'Driscoll (2002). "Knowledge Management in Pursuit of Performance: Insights from Nortel Networks." Management Information Systems Quarterly 26(3): 269-289.

Mata, F. J., William L. Fuerst, and Jay B. Barney (1995). "Information Technology And Sustained Competitive Advantage: A Resource-Based Analysis." MIS Quarterly 19(4): 487.

Maurice, M. (1976). "Introduction Theoretical And Ideological Aspects Of The Universalistic Approach To The Study Of Organizations." International Studies of Management \& Organization 6(3): 3.

Miller, G. A. (1987). "Meta-Analysis and the Culture-Free Hypothesis." Organization Studies 8(4): 309-326.

Mowrer, R. R., and Stephen B. Klein (1989). A Contrast Between Traditional and Contemporary Learning Theory. Contemporary Learning Theories. S. B.
Klein, and Robert R. Mowrer. Hillsdale, NJ, Lawrence Erlbaum Associates.

Ng, P., and Ali Farhoomand (2002). The PricewaterhouseCoopers KnowledgeCurve and the Spinoff of PwC Consulting. Hong Kong, The Centre for Asian Business Cases, University of Hong Kong: HKU221; reprinted by HBS as $02 /$ 147C; 15pp.

Nonaka, I., and Hirotaka Takeuchi (1995). The Knowledge-Creating Company. New York and Oxford, Oxford University Press.

Penrose, E. T. (1959). The Theory Of The Growth Of The Firm. Oxford *Eng.*, Blackwell.

Ramesh, B. and A. Tiwana (1999). "Supporting Collaborative Process Knowledge Management in New Product Development Teams." Decision Support Systems 27(1-2): 213-235.

Rayport, J. F., and Sviokla, J.J. (1995). "Exploiting the virtual value chain." Harvard Business Review 73(6): 75-85.

Rebentisch, E. S. and M. Ferretti (1995). "A Knowledge Asset-Based View Of Technology Transfer In International Joint Ventures." Journal of Engineering and Technology Management 12(1-2): 125.

Rukstad, M. G., and P.Coughlan (2001). DaimlerChrysler Knowledge Management Strategy. Cambridge, MA, HBS: Report No. 9-702-412; 18.

Schultze, U., and D. E. Leidner (2002). "Studying Knowledge Management in Information Systems Research: Discourses and Theoretical Assumptions." Management Information Systems Quarterly 26(3).

Soo, C., T. Devinney, et al. (2002). "Knowledge Management: Philosophy, processes and pitfalls." California Management Review 44(4): 129.

Spender, J.-C. (1996). "Making Knowledge The Basis Of A Dynamic Theory Of The Firm." Strategic Manage- 
ment Journal 17: 45.

Star, S. L. and J. R. Greisemer (1989). "Insitutional Ecology, 'Translations' and Boundary Objects: Amateurs and Professionals in Berkeley's Museum of Vertebrate Zoology, 1907-39." Social Studies in Science 19: 387-420.

Stata, R. (1989). "Organizational Learning: the key to management innovation." Sloan Management Review 30(3): 63-74.

Tien, C.-J., Jui-Hung Ven, and ShohLiang Chou (2003). "Using the problembased learning to enhance student's key competencies." Journal of American Academy of Business, Cambridge 2(2): 454.

Verganti, R. (1998). "Leveraging on Systemic Learning to Manage the Early Phases of Product Innovation Projects." Journal of Product Innovation Management 15(5): 471-472.

Vygotsky, L. S., R. W. Rieber, et al.
(1987). The Collected Works of L.S. Vygotsky. New York, Plenum Press.

Walker, A., Edwin Bridges, and Benjamin Chan (1996). "Wisdom gained, wisdom given: instituting PBL in a Chinese culture." Journal of Educational Administration 34(5): 12.

Walsh, J. P. and G. R. Ungson (1991). "Organizational Memory." Academy of Management Review 16(1): 57-91.

Walsham, G. (2002). "Cross-cultural software production and use: a structurational analysis." MIS Quarterly 26(4): 359-380.

Watson, R. T., Teck Hua Ho, and K. S. Raman (1994). "Culture: a Fourth Dimension of Group Support Systems." Communications of the ACM 37(10): 44-55.

Zull, J. E. (2002). The Art of Changing the Brain: Enriching Teaching by Exploring the Biology of Learning. Sterling, VA, Stylus Publishing, LLC.

Robert M. Mason is Professor of Management Information Systems and Sprint Professor of Business Administration at Florida State University. His undergraduate and masters degrees are in electrical engineering (MIT) and his PhD is in industrial and systems engineering (Georgia Tech). He has spent time in industry and managed his own consulting firm before returning full time to academia. He is a former president of the International Association for the Management of Technology (IAMOT) and serves as an associate editor for Technovation. His research interests include technology management, especially knowledge management and learning, and the cultural issues associated with information technology. 